\title{
CORPORATE SOCIAL RESPONSIBILITY IN SMALL AND MEDIUM ENTERPRISES: EVIDENCE FROM TOURISM SECTOR
}

Nehad Mohamed Kamal Yehia

Hamida Abd El Samie Mohamed

Heba Salah Zaki

Faculty of Tourism and Hotels

University of Sadat City

\begin{abstract}
This study investigates corporate social responsibility (CSR) from the perspective of small medium tourism enterprises (SMTEs) in Egypt. The basic aspects of the investigation were CSR definitions, dimensions, small and medium enterprises (SMEs) importance and characteristics, motivations and benefits from engaging in CSR, the influence of managerial SMEs' characteristics on adopting CSR and the challenges faced. This research used a quantitative method approach to collect data from the owners and managers of (350) SMTEs in Cairo and Giza Category (A) using questionnaire forms. The results of the empirical study showed that although the vast majority of SMTEs were not familiar with the term CSR, most of them were practicing some of its activities. The results also revealed that only the size and age of SMTEs influenced their CSR implementation. While, in relation to SMTEs' managers, only their age and the experience influenced their attitude toward CSR.Finally, this study provided some recommendations that could be considered as guidelines for SMTEs.
\end{abstract}

Keywords: Corporate social responsibility, small and medium enterprises, tourism companies.

\section{INTRODUCTION}

Today, tourism companies became responsible for the destinations where they operate and for the local communities; a responsibility that extends beyond the economic and legal obligations and that is based on creating benefits for both the local community and the organization. This responsibility of the organization with all the stakeholders marked the beginning of Corporate Social Responsibility (CSR) (Kort, 2010).

The recent years have witnessed a significant and growing interest in CSR, and now it becomes an important topic for research (Sweeney, 2009). Porter and Kramer (2006) emphasize that if companies take responsibility to reduce and prevent their negative impact on the social and physical environment, this will achieve several benefits to the society and the environment as well as to the company itself.

Consequently, CSR implementation becomes increasingly important in the tourism industry, because it helps to reduce the negative effects that tourism can cause in the areas where it operates and in its local communities (Kort, 2010). However, CSR initiatives have tended to focus mainly on large and multinational companies (Jenkins, 2006). This is because they tend to be more highly criticized than small and medium enterprises (SMEs) for negatively affecting stakeholders, so the need for these businesses to practice CSR is considered greater (Worthington et al., 2006). It has been noted that research on CSR in SMEs is quite limited especially in developing countries (Cilberti et al., 2008).

SMEs make up a significant proportion of business communities worldwide and have gained wide recognition as a major source of employment, income generation, poverty alleviation and regional development (Spence \& Rutherfoord, 2001; Luetkenhorst, 2004 ; Vives, 2008). As a result of the growing significance of the small and medium- sized enterprise (SME) sector especially in the tourism industry that relies more heavily on SMEs than most other industries, the CSR became important for both large and small tourism enterprises and the research on CSR has been moving toward SMEs in recent years (Yu, 2010).

The empirical studies of CSR in large companies have been reported in many articles and books with little attention paid to empirical research on SMEs (Perrini, 2006). That results in a research gap concerning CSR in SMEs especially in the service sector. As the vast majority of tourism companies in Egypt are small and medium- sized, as well as, CSR practices in SMEs are different from those in large companies due to its unique characteristics, so it is important to study CSR in SMTEs. 


\section{The research was guided by the following objectives:}

a) Identify theoretical insights of CSR; first in a general context and then applied to the small and medium tourism enterprises (SMTEs).

b) Assess the level of awareness and implementation of CSR in the Egyptian small and medium tourism enterprises.

c) Understand how SMTEs characteristics affect their CSR engagement.

d) Explore the factors that motivate SMTEs to adopt CSR and understand the benefits of engaging in CSR programs.

e) Identify CSR activities in SMTEs and examine the challenges that facing CSR in the Egyptian SMTEs.

\section{LITERATURE REVIEW}

\section{CORPORATE SOCIAL RESPONSIBILITY}

Corporate social responsibility (CSR) captures the attention of both academics and practitioners (Henderson, 2007). CSR has relative synonyms such as: corporate citizenship, corporate sustainability, corporate responsibility, or responsible business, and it means dealing with employees, suppliers, and customers, as well as supporting local communities, giving donations to charitable causes and environmental sustainability (Zientara \& Bohdanowicz, 2010 ).

According to various studies from the CSR literature (Carroll, 1999; McWilliams \& Siegel, 2001; Kan et al., 2010), CSR can be broadly defined as the activities making companies good citizens who contribute to society's welfare beyond their own self- interests. It is also considered as a philosophy and policy which benefits the economy, society and environment based on the idea that companies should be responsible for more than simply making a profit and be aware of social values and take part in improving the social environment on top of its economic functions (Henderson, 2007; Taha, 2010; Tsai, Tsang, \& Cheng, 2012). Dahlsrud (2008) also assured that CSR is a widely used term which has different definitions; these definitions are similar to a large extent. He developed five dimensions of CSR; social, environmental, stakeholder, economic and voluntariness dimension. The European Commission (2011: 6) puts forward a new definition of CSR as "the responsibility of enterprises for their impacts on society".

Since the tourism industry largely depends on human and natural resources, on the environment in which their activities take place and in the relationship with stakeholders, and it is closely linked to local communities, CSR, becomes, even more a, relevant issue in this industry (Henderson, 2007). Therefore, the importance of CSR by the travel industry has risen, especially, in recent years along with the environmental issues of degradation, climate change, and reduction of natural resources, human rights issues, and fair trade (Sheldon \& Park, 2010). CSR is also important for tourism business organizations due to its positive impact on reputation, client and employee satisfaction (Dodds \& Kuehnel, 2010).

CSR encompasses notions of business ethics and the importance of owners besides both its internal stakeholders (owners, managers, and employees), and external stakeholders, i.e. the individuals and population groups affected by its activity, including customers and suppliers, other players in the company's value chain, local communities, society in general and future generation (Argandona, 2010). It is also about achieving commercial success in ways that honor ethical values and respect people, communities, and the natural environment (Eraqi, 2010).

There are some studies that examine CSR in tourism (Miller, 2001; Kalisch, 2002; Dodds \& Joppe, 2005; Kasim, 2006; Henderson, 2007;Dodds \& Joppe, 2009; Lee \& Park, 2009; Dodds \& Kuehnel, 2010;Bach et al., 2014). Yet, the vast majority of CSR studies in tourism have largely focused on hotels rather than tour operators and mainly about environmental elements (Dodds \& Kuehnel, 2010). Lee and Park (2009) found that hotel firms' CSR has a positive relationship with financial performance. Despite the benefits for both tourism business organizations and tourism destinations, only two percent of tourism business organizations, all over the world, practice social responsibility (Bach et al., 2014) .Possible reasons for such a low implementation of social responsibility actions resulting from that the decision makers are limited by the 


\section{CORPORATE SOCIAL RESPONSIBILITY IN SMALL AND MEDIUM ENTERPRISES: EVIDENCE FROM TOURISM SECTOR}

available information, the cognitive limitations, and the time available for making the final decision (Bach et al., 2014). One of the major challenges of implementing CSR in the tourism sector is that many of the initiatives remain in the field of philanthropy, achieving improvements in some aspects, but not providing a real impact on the organization and on the society (Bach et al., 2014). CSR is not integrated into the philosophy of the company and it is seen as a complementary issue to be addressed separately from the organization's management (Kort, 2010).

\section{SMALL AND MEDIUM ENTERPRISES}

The concept of CSR and how it is relevant to SMEs has received growing attention in academic literature especially over the last 20 years (Kim, 2009). Lepoutre and Heene (2006) mentioned that CSR in SMEs is important for two main reasons; firstly, SMEs constitute a large proportion of all businesses and contribute significantly to economic development. Secondly, SMEs are different in nature to large firms which may impact on the implementation of CSR. For example, most SMEs are directly managed by owners, are strictly linked to business partners and the local community, and lack resources.

SME is an enterprise which has less than 250 employees, less than 50 million Euros and turnover or total balance sheet of fewer than 43 million Euros (European Commission, 2003). Small and medium enterprises are now recognized as the primary driver of economic development (Spence \& Rutherfoord, 2001). Fox (2005) described them as the bedrock of an economy. SMEs constitute more than $90 \%$ of all companies that exist around the globe and account for between 50 and 60 percent of employment particularly in developing countries, so they are increasingly responsible for the creation of the majority of jobs (Luetkenhorst, 2004; Vives, 2008).

The tourism business sector companies in Egypt is dominated by small-and medium-sized enterprises (SMEs) because about $75 \%$ of them are small enterprises, so they are expected to achieve more success in dealing with social issues and contribute to sustainable tourism development through demonstrating CSR behavior (Eraqi, 2010). Moreover, SMEs in tourism can minimize environmental impacts due to their small scale and because they are more understanding their tourist destinations social and environmental issues compared to large size companies that depend a lot on foreign employees for managing their activities (Eraqi, 2010). Small and medium tourism enterprises can also contribute to strengthening local cultures and customs by providing various tourism activities, and enhance the local economy through transforming local resources into tourist products and services (Kim, 2009).

To promote CSR practices within SMEs, we must realize the special characteristics of these enterprises, which are different and distinguish them from large companies. These characteristics include: SMEs are mostly owner-managed, as a result, decision-making processes are guided by owners' personal values and anticipations rather than long-term planning and rationality and therefore decisions are more reactive in nature than proactive (Sen, 2011). Jenkins (2006; 2009) also indicated that the owner. Manager's personal values and motivations are a key influence on CSR in SMEs. SMEs have a few number of employees compared to large companies which increase the opportunity to develop a personal relationships between the owner-manager and employees, so that work is considered both a technical and a social activity, In some cases the firm can be managed and staffed by family members that lead to greater loyalty (Spence, 1999). Thus, this will have a direct impact on the firm's corporate responsibility (Spence, 1999; Vives, 2005).

Because of their simple organizational structure, SMEs are found to be flexible and adaptable, and can, therefore, respond quickly to stakeholder demands and to changing circumstances (Jenkins, 2006; 2009). SMEs also have the advantage to manage risks and improve reputation as they have much shorter decisionmaking process than large ones (Tsai \& Wang, 2011).SMEs are often creative and innovative which can be applied to the development of innovative approaches to CSR. Through the adoption of CSR in SMEs can be able to develop more innovative products and services than large firms (Jenkins, 2009). One of the SMEs characteristics that affect their CSR adoption is that SMEs are more embedded in the community, as the owners and also employees are usually the local people so they are believed to have stronger relationships with community members, acting as leaders and benefactors (Spence, 1999; Moore \& Spence, 2006). These relationships with community members and other stakeholders lead to an increased understanding of 
stakeholders, which may lead to make them more responsible and increased CSR engagement (Barton, 2010; Dalíková, 2011).

\section{CSR AND SMES}

Mankelow and Quazi (2007) identified the motivational factors for small and medium size enterprises to adopt corporate social responsibility practices as (caring for the customer and society, the financial selfinterest of SMEs or achieving profit as well as growth of their businesses). Seilonen and Hsu (2012) also stated that CSR influence how customers evaluate the company and their purchase intentions, For example, customers are more supportive to the companies that adopt CSR strategy than companies without CSR agenda. It has also been acknowledged that CSR can provide a competitive advantage for SMEs through providing a more important profile and market position (Jenkins, 2006; Murillo \& Lozano, 2006; Perrini, 2006).Abou Taleb and Fahmi (2013) proved that hotels and travel agencies' CSR actions have significant positive influence on customer satisfaction, customers' commitment, and customer loyalty. Santos (2011) mentioned that there is a positive and significant statistical relationship between involvement in external CSR activities and the age of the company, this means that CSR increases with the number of years that the company has been in business.

It has been argued that small firms are conducting CSR and not communicating it, or may not even realize they are in fact conducting CSR (Prinic et al., 2003; Perrini, 2006). Perrini (2006) referred to the "silent CSR" or "sunken CSR" practiced by SMEs, suggesting that SMEs are often "unknowingly socially responsible'. Corporate social responsibility commitments are maintained and advanced by organizations' managers (Quazi, 2003). Therefore, the attitudes of owners and managers are a most important element in determining their behaviors toward social responsibility (Dewhurst \& Thomas, 2003). The responsible behaviors of small, family-owned businesses in terms of environmental and social practices have been argued in the tourism literature (Carlsenet etal., 2001). Moreover, some studies (Longnsecker et al., 1989; Serwinek 1992; McDonald \& Kan, 1997; Quazi 2003; Kim, 2009) have examined whether personal characteristics affect managers' and owners' attitudes toward sustainable development and responsibility. Therefore, there is a need to understand managers' attitudes of small and tourism companies toward CSR. This study will examine the activities and attitude of SMTEs toward CSR as well as understand how CSR attitudes affect the activities of organizations. These characteristics include:

\section{- Age}

Generally, the studies suggested that the age of managers has an effect on their attitude toward CSR based on the assumption that older people are more conservative. For example, Longnsecker et al. (1989) found that younger people tended to be less sensitive in their moral judgments than older people. Some studies also supported this finding that older adults tended to have stronger ethical beliefs (Arlow, 1991; McDonald \& Kan, 1997). However, some studies (Carlsen, et al., 2001; Quazi, 2003; Kim, 2009) found that age did not affect attitude toward CSR.

\section{- Education}

Quazi (2003) reported that the higher the level of education the more likely respondents were to understand the issues of CSR. However, Serwinek (1992) and Kim (2009) found that education level was not a determinant of attitudes toward social responsibility.

\section{- Length of work experience}

Regarding the length of work experience, previous studies found mixed results. Most studies found that an employee with more work experience might show more ethical trends and is more likely to agree with ethical activities (McDonald \& Kan, 1997; Kim, 2009). However, in contrast, Arlow (1991) found no significant relationship between the length of work experiences and attitudes toward social responsibility.

There are difficulties associated with CSR in SMEs as a result of limited resources. However, rather than considering difficulties as a barrier, they could be approached as a challenge that needs to be overcome through innovation (Jenkins, 2006). A lack of time seemed to be another significant barrier (Jenkins, 2006). In the context of CSR, owner-managers are often having a lasting lack of time as they are often multi-tasking and focusing not only on managing the business. but also on the day-to-day functional aspects of keeping the business running (Spence, 1999; Worthington, et al., 2006). Another factor hindering adoption of CSR are 


\section{CORPORATE SOCIAL RESPONSIBILITY IN SMALL AND MEDIUM ENTERPRISES: EVIDENCE FROM TOURISM SECTOR}

the lack of financial resources, It is well known that most SMEs are suffering from a lack of financial resources, This barrier is perceived as especially high when it is believed that little or no economic return will result from the initial investment (Worthington, et al., 2006). According to Lepoutre and Heene (2006) CSR activities are perceived as costs which, if undertaken will place them at a competitive disadvantage.

Another barrier to CSR in SMEs is that the difficulties in measuring the impact of such practices. Because most benefits of CSR are intangible, so it is difficult for SME to measure and quantify (Jenkins, 2006; Jäger, 2012). The tension between short-term and strategic returns from CSR activities is also considered another barrier, a large number of small- and medium-sized hotels have not seen the benefits of doing corporate socially responsible activities due to the short-term costs even when long-term cost savings are expected (Yu et al., 2012). According to Spence (1999). Graafland et al., (2003) Moore \& Spence (2006), SMEs characterized by informality, and therefore the large-firm language of CSR, such as vision statements, mission statements, and strategic approach is not commonly used in SMEs.

A lack of skill and knowledge is another barrier that limits SMEs engagement in CSR. Roberts et al. (2006) assumed that the lack of knowledge is a result of lack of time and money because the owner-managers haven't the skills to prioritize CSR management and to accurately assess the time and money required for CSR activities. This lack of knowledge may prevent SME owner-managers from considering CSR and realizing its significance and potential benefits (Perrini, 2006).

Dzansi (2004) also argued that the lack of technology, expertise and training constitute barriers for CSR in SMEs. Jenkins (2006) and Perrini (2006) mentioned that the lack of support or power and influence may also act as a barrier to CSR for SMEs. This is referring both to practical services and financial support such as tax reduction and subsidies (Jenkins, 2006 \& Perrini, 2006).

Some of the most common examples of CSR in SMEs include donating to local causes and charities, sponsorship of local events and organizations, support for local schools colleges, environmental initiatives, ethical purchasing and staff related activities (Worthington et al., 2006). The nature of CSR activities in SMEs can be significantly different from those activities in large enterprises, for example: the relationships between SMEs and their key stakeholders (especially employees and customers) are characterized by a high level of informality, relations with customers who are usually depend on personal knowledge of customer's needs, while relations with employees are more family like (Turyakira et al., 2013) as they are generally living in the same place. Mandl and Dorr (2007) demonstrated that CSR activities in SMEs are particularly focused on market-orientated, workforce-orientated, society-orientated, and environment-orientated.

The recent study aims to test the following hypotheses:

H1: There are significant relationships between SMTEs' characteristics (number of employees, the age of the company, ownership status) and adopting CSR.

H1a: There is a significant relationship between the company's size and adopting CSR.

H1b: There is a significant relationship between the company's age and adopting CSR.

H1c: There is a significant relationship between ownership type of the SMTEs and adopting CSR.

H2: There are significant relationships between managerial characteristics of SMTEs' managers (age, education level, work experience in tourism industry) and their attitude toward CSR.

H2a: There is a significant relationship between managers' ages and their attitudes toward CSR.

H2b: There is a significant relationship between managers' education levels and their attitudes toward CSR.

H2c: There is a significant relationship between managers' work experiences in the tourism industry and their attitudes toward CSR. 


\section{METHODOLOGY}

\subsection{DATA COLLECTION TECHNIQUE AND RESPONSE RATE}

This research used questionnaire instrument to collect statistical data about the characteristics of the respondent SMTEs, their attitudes toward social responsibility, the corporate socially responsible practices they engage in, the benefits and barriers for implementing CSR. The questionnaire consisted of seven sections.

Section A concerned with demographic purposes about the respondents. The questions included job position, education, age and experience in the tourism industry. Section $\mathbf{B}$ gathered information assessing the respondent's company profile, such as the number of employees, the age of the company and whether the business is owner-managed or family-owned, these were identified in the literature as characteristics that may affect CSR engagement. Section $\mathbf{C}$ of the questionnaire aims at knowing if the company is familiar with CSR, management of CSR and to what extent it practices social responsibility. Section $\mathbf{D}$ measured the respondents' attitudes toward CSR through fourteen items. Section $\mathbf{E}$ measured motivations of CSR in SMTEs. Section $\mathbf{F}$ identified behavior or activities of CSR in small and medium tourism enterprises. Finally, Section $\mathbf{G}$ designed to gather information about the barriers of CSR in SMTEs.

The data of the study was collected from Egyptian tourism companies through distributing 350 questionnaire forms among small and medium tourism companies' managers and department managers. There were 303 questionnaire forms that were distributed correctly and successfully recollected with an approximate response rate of $86.5 \%$ of the total sample (350 SMTEs).

\section{Data ANAlysis}

The data analysis in this study consisted of several steps. Firstly, descriptive analyses were performed to investigate the frequency distribution of responses to the relevant questions, standard of deviation and mean. Descriptive research "involves the presentation of information in a fairly simple form" (Veal, 2006:306).These questions were composed of respondents' characteristics and their attitudes on SMTEs' social responsibility, SMTEs' motivations for CSR, SMTEs' socially responsible practices, benefits and barriers of CSR in SMTEs. To get the findings of these analyses, the statistical package for social science (SPSS) was used. Secondly, Explanatory research examines regressions, and is able to reveal relationships between two or more variables (Veal, 2006). Correlation, cross-tabulation, independent t-tests and one way ANOVA were used as a form of explanatory research to expose the possible significance of these relationships.

\section{RESULTS AND DISCUSSION}

\section{A) Respondents' Profile}

Regarding respondents position, the results indicate that (22.4\%) of respondents are owners and (32.7\%) are owner-managers. Moreover, a percentage of (14.2\%) respondents are general managers and (30.7\%) of the sample was department managers. Regarding the educational degree of respondents, the vast majority of respondents $(81.5 \%)$ are college graduated, while post graduated represents $(11.9 \%)$ and only $(6.6 \%)$ of respondents are less than college. As for the age, (37.9\%) of respondents are less than forty years while $(44.9 \%)$ are between (40) and (50) years and (15.5\%) are between (51) and (60) years. Finally, only five respondents with a percentage of (1.7\%) are between (61) and (70) years. Concerning the period of working in the tourism field, (43.9\%) of respondents have experience in tourism field ranging between one and ten years, while (41.3\%) have experience between (11) and (20) years. Moreover, a percentage of (14.9\%) respondents have experience for more than twenty years.

\section{B) Firms' Profile}

Regarding the foundation date of firms, a percentage of (43.2\%) was founded since eleven and twenty years, while a percentage of $(40.3 \%)$ ranged between one and ten years. Only, $(16.5 \%)$ of firms was founded since more than twenty years. Results also reveal that more than half the sample (50.8\%) represents those firms with (10-50) employees (small sized firms) while, micro businesses were accurately represented with (34.3\%) being included in the survey. Medium businesses (51-250 employees) were represented with 14.9\% of the sample. It is noticeable that the largest part of the sample is small sized firms, this happens because of the revolution of 25 January which reduced the number of workers in the tourism companies. The vast 


\section{CORPORATE SOCIAL RESPONSIBILITY IN SMALL AND MEDIUM ENTERPRISES: EVIDENCE FROM TOURISM SECTOR}

majority of the sample $(87.1 \%)$ were family-owned companies (owned and managed by one or more members of the same family), while, only a percentage of (12.9\%) was not family-owned, they have some other forms of ownership structure, such as a partnership. This is in line with the literature which clarified that SMEs are mostly family-owned.

\section{C) Adoption of CSR in SMTEs}

Respondents were asked to state the extent to which they agreed with the statement "Our firm is a socially responsible firm". Table 1 illustrates the responses to this question.

Table 1 the Extent of practicing social responsibility

\begin{tabular}{|c|c|c|}
\hline Extent of Practicing & Frequency & Percent \\
\hline No action & 104 & $34.3 \%$ \\
\hline Small action & 129 & $42.5 \%$ \\
\hline Medium action & 12 & $4 \%$ \\
\hline Quite extensive action & 26 & $8.6 \%$ \\
\hline Extensive action & 32 & $10.6 \%$ \\
\hline Total & 303 & $100 \%$ \\
\hline
\end{tabular}

Results revealed that $(34.3 \%)$ of the sample rated themselves as not practicing CSR. While only $19.2 \%$ (either agree or strongly agree) of respondents believe their firm is socially responsible with quite and extensive action. As for those who chose small and medium action (46.5\%), it indicates that businesses tend to take some form of CSR actions but they didn't familiar with the term and didn't use it, they could be considered as silent CSR practicing. It has been noted in the literature that SMEs are often involved in CSR and do not call it CSR or may not even be aware of it (Prinic et al., 2003; Perrini, 2006). Perrini (2006) pointed to the "silent CSR" or "sunken CSR" practiced by SMEs.

The one-way ANOVA test was used to examine whether the characteristics of SMTEs (age and size) affected the adoption of CSR.

- Size of SMTEs and adopting CSR

Table 2 One-way ANOVA for impact of SMTEs size on adopting CSR

\begin{tabular}{|c|c|c|c|c|c|c|}
\hline & & $\begin{array}{l}\text { Sum of } \\
\text { Squares }\end{array}$ & df & $\begin{array}{l}\text { Mean } \\
\text { Square }\end{array}$ & $\mathrm{F}$ & Sig. \\
\hline \multirow[t]{3}{*}{ size } & Between Groups & 73.427 & 4 & 18.357 & 85.361 & .000 \\
\hline & Within Groups & 64.084 & 298 & .215 & & \\
\hline & Total & 137.512 & 302 & & & \\
\hline
\end{tabular}

As table (2) shows, the ANOVA test result of $\mathrm{p}$ - value $=.000$ indicates a statistically significant relationship between the size of SMTEs and implementing CSR. Hence, hypothesis H1a was accepted. 
- Age of SMTEs and adopting CSR

Table 3 One-way ANOVA for impact of SMTEs age on adopting CSR

\begin{tabular}{|c|c|c|c|c|c|c|}
\hline & & $\begin{array}{c}\text { Sum of } \\
\text { Squares }\end{array}$ & df & $\begin{array}{c}\text { Mean } \\
\text { Square }\end{array}$ & F & Sig. \\
\hline & Age Between & 92.221 & 4 & 23.055 & $\begin{array}{c}109.63 \\
0\end{array}$ & .000 \\
& Groups \\
& Within Groups & 62.670 & 298 & .210 & & \\
\hline & Total & 154.891 & 302 & & & \\
\hline
\end{tabular}

As table 3 shows, the ANOVA test result of $\mathrm{p}$ - value $=.000$ indicates a statistically significant relationship between the age of SMTEs and implementing CSR. Hence, hypothesis H1b was accepted.

\section{- The SMTEs ownership and adopting social responsibility}

An independent sample t-test was conducted to find whether any significant difference existed between ownership status and adoption of CSR. The results revealed that $(\mathrm{t}=1.217, \mathrm{p}=.229)$, which means that there is no statistically significant difference was found between ownership status and adoption of CSR. Hence, hypothesis H1c was rejected. These findings are contradicted to what argued in the literature, (Spence, 1999; Vives, 2005) that the firm can be owned and staffed by family members. Consequently, this will have a direct impact on the firm's corporate responsibility. 


\section{CORPORATE SOCIAL RESPONSIBILITY IN SMALL AND MEDIUM ENTERPRISES: EVIDENCE FROM TOURISM SECTOR}

\section{D) Attitude of SMTEs managers toward CSR}

To understand the SMTEs' attitudes towards implementing CSR, respondents were asked to rate their level of agreement with a number of CSR attitude statements listed below in (table 4).

Table 4 Attitude of SMTEs toward CSR

\begin{tabular}{|l|c|c|c|}
\hline \multicolumn{1}{|c|}{ Attitudes of SMTEs toward CSR } & N & Mean & Std. Deviation \\
\hline CSR is very important to SMTEs. & 303 & 4.53 & .562 \\
\hline CSR is critical to the survival of the organization. & 303 & 3.68 & .953 \\
\hline The success of the organization is linked to CSR practice. & 303 & 3.59 & .934 \\
\hline CSR can improve the employee performance. & 303 & 4.57 & .522 \\
\hline CSR can lead to employee morale. & 303 & 4.49 & .545 \\
\hline CSR is more important than economic goals (e.g. profit). & 303 & $\mathbf{1 . 9 2}$ & $\mathbf{1 . 1 3 5}$ \\
\hline $\begin{array}{l}\text { Organization should be responsible for preserving the } \\
\text { local culture. }\end{array}$ & 303 & 4.56 & .497 \\
\hline $\begin{array}{l}\text { Organization should be responsible for protecting the } \\
\text { environment. }\end{array}$ & 303 & 4.64 & .482 \\
\hline $\begin{array}{l}\text { Organization should have a responsibility to develop the } \\
\text { local community. }\end{array}$ & 303 & 4.56 & .497 \\
\hline $\begin{array}{l}\text { Organization's customers are influenced by its CSR. } \\
\text { CSR is important to the competitiveness. }\end{array}$ & 303 & 3.82 & .920 \\
\hline $\begin{array}{l}\text { CSR is important to achieve long-term profitability. } \\
\text { organizations over the next five years. }\end{array}$ & 303 & 4.25 & .568 \\
\hline $\begin{array}{l}\text { My organization will work with CSR in the future. } \\
\text { Total attitude }\end{array}$ & 303 & 4.71 & .455 \\
\hline
\end{tabular}

As shown in table (4), the agreement level of respondents with all statements was positive with total mean (4.196) and standard deviation (.293). The standard deviation of mean ranges from (0.38) to (1.13) which mean that it is small and mean difference ranges from (1.92) to (4.82) which means that most SMTEs attitudes were far away from the scale of strongly disagree and disagree - except one item" CSR is more important than economic goals"- but near to the scale of agree, strongly agree. This, in turn, assures that SMTEs managers have a positive attitude toward CSR.

\section{- Age and Attitude}

Table 5 the relationship between age of SMTEs ' managers and their attitudes toward CSR 


\begin{tabular}{|c|c|c|c|}
\hline & & Age & Attitude \\
\hline \multirow{2}{*}{ Age } & Pearson Correlation & 1 & $.502^{* *}$ \\
& Sig. (2-tailed) & & .000 \\
& $\mathrm{~N}$ & 303 & 303 \\
\hline Attitude & Pearson Correlation & $.502^{* *}$ & 1 \\
& Sig. (2-tailed) & .000 & \\
& $\mathrm{~N}$ & 303 & 303 \\
\hline
\end{tabular}

**Correlation is significant at the 0.01 level (2-tailed)

The Pearson Correlation in (Table 5) was used to examine the relationship between age of SMTEs' managers and their attitude toward CSR. The analysis showed that the correlation was statistically significant at the (0.01) level. The correlation between age and attitude toward CSR was (.502) the two variables were positively correlated with each other, indicating that as manager age increased, so did the manager positive attitude towards CSR. This is in line with previous research (Longnsecker et al. 1989; McDonald \& Kan 1997; Serwinek 1992) which suggested that older respondents tend to have stronger ethical beliefs and be more sensitive to ethical issues. Hence, hypothesis H2a was accepted.

\section{Educational Level and Attitude}

Table 6 the relationship between education level of SMTEs ' managers and their attitudes toward CSR

\begin{tabular}{|l|c|c|c|}
\hline & & Attitude & Education \\
\hline \multirow{2}{*}{ Attitude } & Pearson Correlation & 1 & $-.111-$ \\
& Sig. (2-tailed) & & .053 \\
& $\mathrm{~N}$ & 303 & 303 \\
\hline Education & Pearson Correlation & $-.111-$ & 1 \\
& Sig. (2-tailed) & .053 & \\
& $\mathrm{~N}$ & 303 & 303 \\
\hline
\end{tabular}

The Pearson Correlation Table 6 was used to examine the relationship between the level of education and attitude towards CSR. The analysis indicates a non-significant relationship between the educational level of SMTEs' managers and their attitude toward CSR, as the value of $\mathrm{P}>.05$. The result of the correlation between education level and attitude towards CSR indicted that there is no relationship between the two variables. This is in line with the arguments of Serwinek (1992) who found that education level was not a determinant of attitudes toward social responsibility. Hence, hypothesis $\mathbf{H 2 b}$ was rejected. 


\section{CORPORATE SOCIAL RESPONSIBILITY IN SMALl AND MEDIUM ENTERPRISES: EVIDENCE FROM TOURISM SECTOR}

\section{- Work Experience and Attitude}

Table 7 the relationship between work experience of SMTEs ' managers and their attitudes toward CSR

\begin{tabular}{|c|c|c|c|}
\hline & & Attitude & Experience \\
\hline Attitude & Pearson Correlation & 1 & $.518^{* *}$ \\
& Sig. (2-tailed) & & .000 \\
& $\mathrm{~N}$ & 303 & 303 \\
\hline Experience & Pearson Correlation & $.518^{* * *}$ & 1 \\
& Sig. (2-tailed) & .000 & \\
& $\mathrm{~N}$ & 303 & 303 \\
\hline
\end{tabular}

**Correlation is significant at the 0.01 level (2-tailed).

The Pearson Correlation in (Table 7) was used to examine the association between the experience of SMTEs manager in the tourism field and attitude toward CSR. The analysis showed that the correlation was statistically significant at the 0.01 level. The correlation between the experience of SMTEs manager and attitude toward CSR was (.518) the two variables were positively correlated with each other, indicating that as manager's experience in tourism field increased, so did the manager positive attitude toward CSR. These findings came to agree with McDonald and Kan (1997) who revealed that an individual with more business experience is more likely to agree with ethical activities. Hence, hypothesis H2c was accepted.

\section{E) Motivations for practicing CSR}

Respondents were asked to identify factors that motivate their firms to adopt CSR.

Table 8 Motivations of adopting CSR

\begin{tabular}{|c|c|c|c|}
\hline Motivations of CSR & $\mathbf{N}$ & Mean & Std. deviation \\
\hline To protect the environment. & 303 & $\mathbf{4 . 8 0}$ & .436 \\
\hline To meet legal requirements. & 303 & 4.02 & .518 \\
\hline Response to customer demand. & 303 & $\mathbf{3 . 8 5}$ & .726 \\
\hline Adding value to my products and services. & 303 & 4.29 & .584 \\
\hline Caring for society. & 303 & $\mathbf{4 . 8 0}$ & $\mathbf{. 4 3 3}$ \\
\hline To build/maintain company goodwill / image. & 303 & 4.13 & .614 \\
\hline To motivate Staff. & 303 & 3.99 & $\mathbf{. 7 9 7}$ \\
\hline Total motivations & 303 & 4.00 & .622 \\
\hline To remain competitive in the global market. & 303 & 4.00 & .609 \\
\hline Personal values of owner-manager. & 303 & 4.79 & .453 \\
\hline
\end{tabular}


As shown in table (8), the respondents indicated that there are many factors that play an important role in motivating firms to undertake CSR. The most motivating factors are respectively: protecting the environment, caring for society and personal values of owner-manager with mean $(\mathrm{M}=4.80,4.80 \& 4.79)$. It is clear that these factors are ethical. These findings support the arguments made in the literature (Jenkins, 2006; Perrini, 2006; Prinic et al., 2003) that SMEs are motivated to conduct CSR from an ethical or philanthropic point of view. Other important motivators include: adding value to my products and services $(\mathrm{M}=4.29)$, build/maintain company goodwill / image $(\mathrm{M}=4.13)$ and meet legal requirements $(\mathrm{M}=4.02)$. This is in line with the argument made by Williamson et al. (2006) that SMEs were motivated to participate in CSR due to legal requirements and business benefits. Respondents stated that meet stakeholder expectations and remain competitive in the global market are considered motivational factors for CSR with the same mean value $(M=4.00)$. Figure 1 illustrates the previous results.

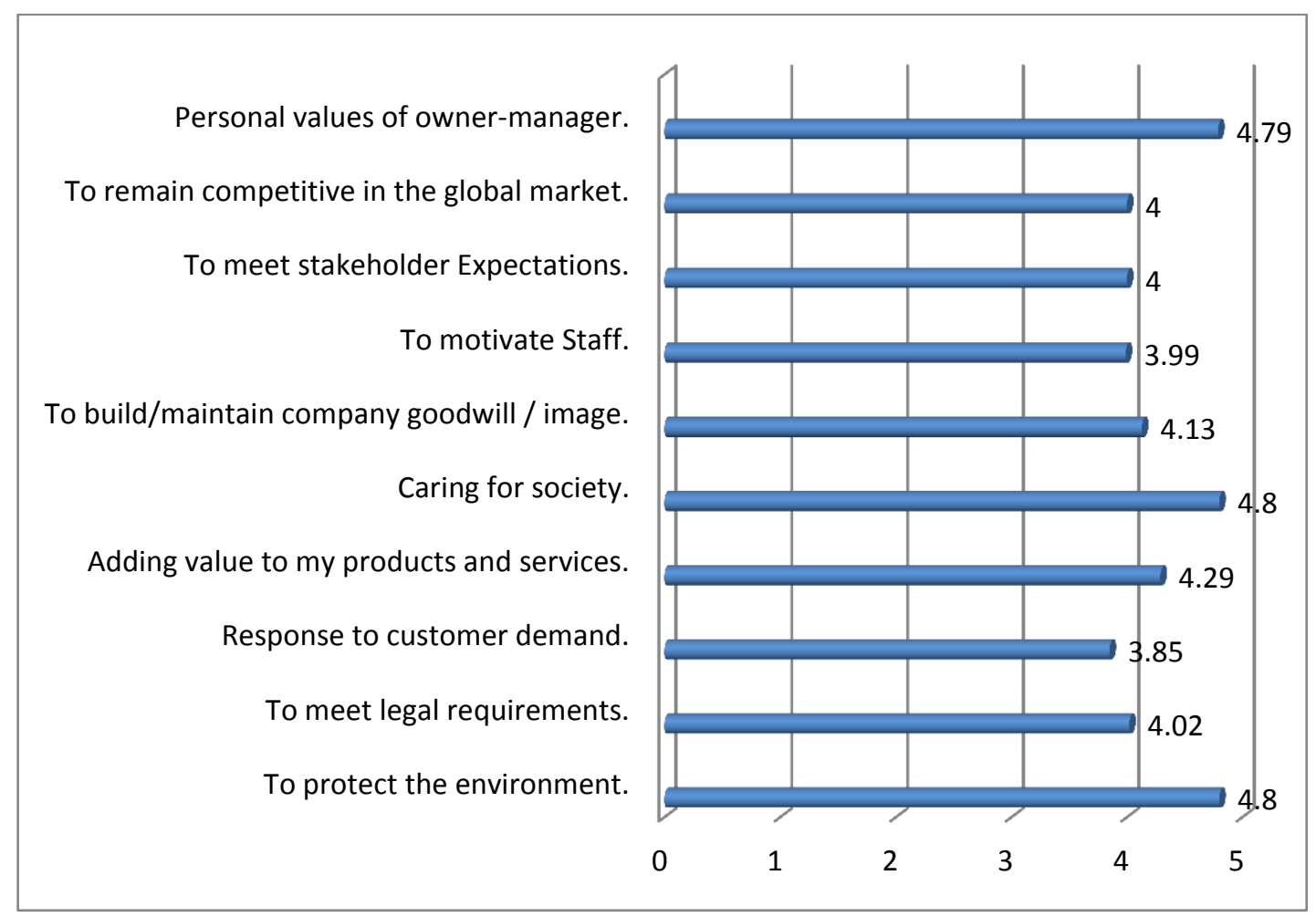

\section{Figure 1: Motivations of adopting CSR}

\section{F) Activities of CSR}

In line with current literature (Jenkins, 2006; Mandl and Dorr, 2007 \& Sweeney, 2009), CSR was viewed to be implemented through stakeholder theory or the "target group" of CSR activities, and the key stakeholders that companies engaged with were the environment, employees, community, and the customers. The relative importance of who varied from company to company. For some companies, environmental management is a key part of CSR, for others employees, the community or customers represent the central part of their activities. Due to the large volume of respondents who indicate that they are not socially responsible, table (9) illustrated that total activities are low to some extent ( $\mathrm{M}=2.59$ and std. 1.04). Data in table (9) showed that the most common activities among respondents are respectively company gives the first preference to local employment and purchase resources from local suppliers ( $\mathrm{M}=4.83$ and 4.80) with standard deviation (.459 and .402). These results due to that approximately all samples - either adopt or not adopt CSR implemented these two activities. Followed respectively by: explaining appropriate behavior while visiting natural areas, living cultures and cultural heritage sites $(\mathrm{M}=3.72 \&$ std. $=1.46)$, encourage customers to consume / use local products $(\mathrm{M}=3.71 \& \mathrm{std} .=.866)$, employees participate in company decisions $(\mathrm{M}=3.29$ $\&$ std. $=1.70)$, resolve customer complaints in a timely manner $(\mathrm{M}=3.20 \&$ std. $=1.17)$, and wages structure are fair and equitable $(\mathrm{M}=3.20 \&$ std. $=1.60)$. 


\section{CORPORATE SOCIAL RESPONSIBILITY IN SMALL AND MEDIUM ENTERPRISES: EVIDENCE FROM TOURISM SECTOR}

Table 9 CSR Activities

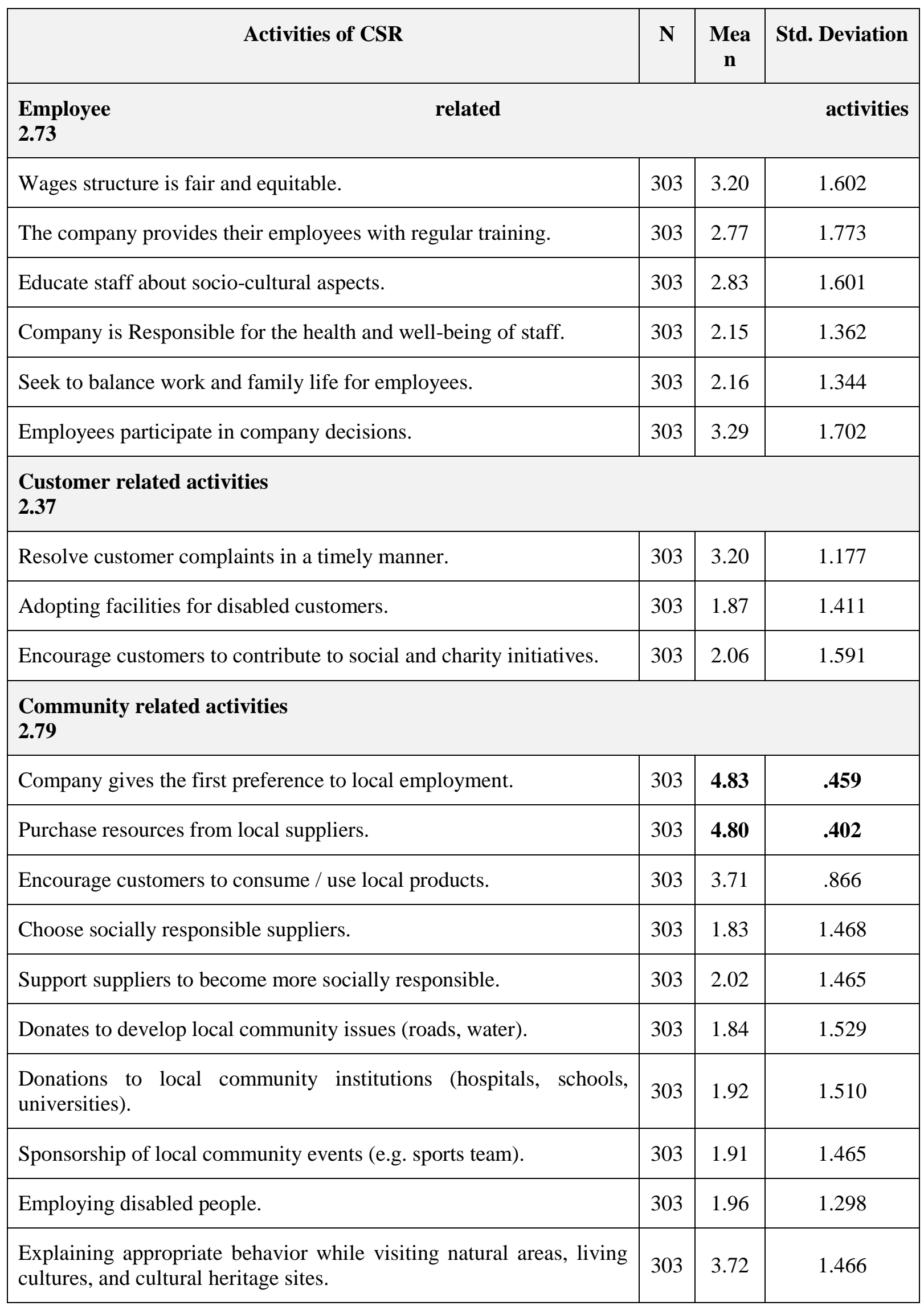




\begin{tabular}{|l|c|c|c|}
\hline Employees involved in charity volunteer work on behalf of the firm. & 303 & 2.16 & 1.493 \\
\hline $\begin{array}{l}\text { Environmental related practices } \\
\mathbf{1 . 8 2}\end{array}$ & \begin{tabular}{l}
$\mid$ \\
\hline $\begin{array}{l}\text { Following friendly environmental practices (e.g. recycling, waste } \\
\text { reduction). }\end{array}$
\end{tabular} & 2.38 & 1.683 \\
\hline Having any certification concerning the environment protection & 303 & 1.75 & 1.459 \\
\hline Writing an environmental report about their activities. & 303 & 1.33 & .734 \\
\hline Total activities & 303 & 2.595 & 1.04803 \\
\hline
\end{tabular}

These results may also trace to the former reason, because these activities are sometimes considered as common actions and the vast majority of firms implement it regardless of CSR. As shown in table (9), the environmental related activities were the least common activities (total environmental activities $\mathrm{M}=1.82$ ) as follows: Following friendly environmental practices (e.g. recycling, waste reduction) (Mean= 2.38 \& std.=1.683), having any certification concerning the environment protection ( Mean= $1.75 \&$ std. $=1.459$ ) and writing environmental report about their activities (Mean=1.33 \& std.=.734), because who cares to apply these activities are those who extensively adopt CSR and they are a little proportion of the sample. This result came to agree with the findings of Vives (2005) study which indicated that the environmental efforts are less common as they are issues of relatively recent concern. Community-related CSR practices were the most common type with a total mean $(M=2.79)$. Table (9) shows the social activities like, with the exception of local employment and purchase resources from local suppliers, explaining appropriate behavior while visiting natural areas, living cultures, and cultural heritage sites $(\mathrm{M}=3.72)$ and encourage customers to consume / use local products $(\mathrm{M}=3.71)$ having the highest scores. As for employee- related practices, firms have adapted activities which are benefits to the employees in the organization. Although they have not thoroughly aware of the word CSR but they have adapted some CSR activities in their organization to benefit their employees. The most common employees, activities are respectively employees participate in company decisions $(M=3.29)$, wages structure are fair and equitable $(M=3.20)$, educate staff about sociocultural aspects $(\mathrm{M}=2.83)$ and the company provides their employees with regular training $(\mathrm{M}=2.77$. The least common employee activity is the company's responsibility for the health and well-being of staff $(\mathrm{M}=2.15)$ because the vast majority of firms haven't health insurance for employees, but only some firms provide their patient's employees with financial aid. 


\section{CORPORATE SOCIAL RESPONSIBILITY IN SMALL AND MEDIUM ENTERPRISES: EVIDENCE FROM TOURISM SECTOR}

\section{E) Barriers to adopting CSR}

Respondents were asked to identify factors that act as barriers to furthering their firm's CSR activities.

Table 10 Barriers to adopting CSR

\begin{tabular}{|l|c|c|c|}
\hline \multicolumn{1}{|c|}{ Barriers of CSR } & N & Mean & Std. deviation \\
\hline Lack of time. & 303 & 1.70 & .906 \\
\hline Lack of money. & 303 & 3.93 & 1.493 \\
\hline Lack of skills. & 303 & 3.88 & .897 \\
\hline The customers haven't asked for it. & 303 & 3.01 & 1.211 \\
\hline Lack of knowledge about CSR programs. & 303 & $\mathbf{4 . 5 6}$ & .497 \\
\hline Lack of support. & 303 & $\mathbf{4 . 5 9}$ & .493 \\
\hline Getting employees involved. & 303 & 2.71 & .843 \\
\hline Embedding CSR culture in the company. & 303 & 3.06 & 1.182 \\
\hline Measuring and quantifying CSR benefits. & 303 & 3.16 & 1.151 \\
\hline Personal values of owner-manager. & 303 & 2.40 & 1.457 \\
\hline
\end{tabular}

As shown in table (10), the results revealed that lack of support $(\mathrm{M}=4.59)$ and lack of knowledge about CSR programs $(M=4.56)$ were considered to be the largest barriers that most affect CSR engagement. While, lack of time $(\mathrm{M}=1.70)$ was the least influential barriers.These findings contradict to current literature (Prinic et al., 2003 \& Vives, 2005; Jenkins, 2006 ; Lepoutre \& Heene, 2006 ) which stated that the two most fundamental challenges that all companies faced, regardless of sector or size, are time and financial resources. The lack of money seemed to be a particularly significant barrier $(\mathrm{M}=3.93)$ but wasn't the greatest. This study came to agree with most studies (Jenkins, 2006; Lepoutre \& Henne, 2006; Perrini, 2006 ; Roberts et al, 2006 ; Vives, 2006 ) which identified human resources constraints as a barrier to CSR such as: lack of knowledge about CSR programs ( $M=4.56)$, lack of skills $(M=3.88)$, embedding CSR culture in the company $(\mathrm{M}=3.06)$, getting employees involved $(\mathrm{M}=2.71)$ and personal values of owner-manager $(\mathrm{M}=2.40)$.Measuring and quantifying CSR benefits $(\mathrm{M}=3.16)$ was also a barrier to CSR, this is in line with (Jenkins, 2006; Jäger, 2012) arguments that considered measuring and quantifying CSR benefits as a barrier because most benefits of CSR are intangible, so it is difficult for SME to measure and quantify. The customers haven't asked for CSR came as a barrier with mean $(\mathrm{M}=3.01)$.

\section{CONCLUSION AND RECOMMENDATIONS}

The review of literature found that whilst SMEs have several characteristics which may make them inherently more likely to practice CSR than larger businesses, they also face many barriers to engaging in CSR. From the practical study, it was concluded that the great majority of respondents were not familiar with the term CSR. Regarding an organization's characteristics, the results indicated that only organizational size and age were significantly related to implementing CSR. With regard to ownership type and management structure, there is no statistically significant difference was found between each of the family owned and not family owned SMTEs, as well as the owner managed and the non owner managed SMTEs in relation to adopting CSR. The findings of this research also indicated that the most motivating factors to participate in 
CSR were respectively: protecting the environment, caring for society and personal values of ownermanager. It is clear that these factors are ethical or moral. Similar conclusions were drawn by Jenkins (2006) from an analysis socially responsible SMEs in UK. It is worth noted that owner-managed SMTEs are generally motivated to engage in CSR by the owner-manager's ethical and personal values, whereas non owner-managed SMTEs tend to be motivated by business reasons including response to customer demand, meet legal requirements, maintain company image, adding value to the companies' services and remain competitive in the global market. With regard to currently CSR activities being undertaken by SMTEs in Egypt, this study revealed that the community related activities were the most cited category, followed by respectively employee, customer and finally environmental related activities. This study also revealed that there is a positive relationship between the attitude of SMTEs toward CSR and SMTEs' activities of CSR. The main barriers to undertake CSR experienced by SMTEs are a lack of support and lack of knowledge about CSR programs, followed by lack of money and lack of skills. The examination of the relationships between the demographic and job-related factors of SMTEs' managers and their attitude toward CSR revealed that only age and length of work experience in tourism field had significant influences on SMTEs' attitudes toward corporate social responsibility. On the other hand, the educational level of SMTEs' managers did not have any effect on SMTEs' attitudes toward CSR.

The recent study recommends some insights that are derived from the barriers listed above:

A large number of SMTEs' managers have been realized that being responsible is expensive; they considered CSR extra expenses. Therefore, to overcome this barrier, their awareness of the potential benefits of CSR must be raised. Another important recommendation is to make the strategy of involvement as simple as possible, trying to encourage one achievement at a time. Moreover, many SMTEs should realize that they are already engaged in what called CSR but they do not call it by that name, or they may not even know about CSR. Their involvement is informal, gradual, and almost unnoticeable (Vives, 2008). The implementation of CSR in SMTEs can be supported also by using simple tools. For instance, one of the most effective ways to do so is by disseminating models of practices carried out by their peers. The government should also assist SMTEs to implement CSR through e.g. (providing loans, providing tools and training for employees to become more environmentally and socially responsible). Besides, marketing efforts to support the implementation CSR reporting and certification system must be fostered. Large businesses can also offer financial or non-financial support to help SMTEs beginning the suggested CSR initiatives.One of the most important barriers for implementing CSR in SMTEs is the limited knowledge among small and medium firms' managers and workers about CSR. Therefore, the main important two concerns needed here are the increasing knowledge of CSR among managers and employees, and also developing clear social responsibility guidelines to follow from the leaders because SMTEs will not engage if they are not fully able to understand the content of such information.

\section{References}

1. Abou Taleb, M. and Fahmi, T.M. (2013). The influence of corporate social responsibility on customer Loyalty: Evidence from the travel Agencies and hotels. Faculty of Tourism and Hotels Journal, Fayoum University, 7(1), 214-231.

2. Argandona, A. (2010). Corporate social responsibility in the tourism industry: Some lessons from the Spanish experience, IESE Business School, University of Navarra. Retrieved 10 Jan 2013 from: http://www.iese.edu/research/pdfs/di-0844-e.pdf.

3. Arlow, P. (1991). Personal characteristics in college Students: Evaluations of business. Journal of Business Ethics, (10), 63-69.

4. Austrian Institute for SME Research (2007). Corporate Social Responsibility in SMEs: Practical examples to foster SMEs' competitiveness, Based on the study "CSR and Competitiveness. European SMEs' Good Practice. Retrieved 3 May 2013 from: http://www.csr-insmes.eu/downloads/brochure_english.pdf.

5. Bach, M. P.; Zoroja, J. and Merkac-Skok, M. (2014). Social responsibility in tourism: System archetypes approach. Kybernetes, 43(3/4), 587-600. 


\section{CORPORATE SOCIAL RESPONSIBILITY IN SMALL AND MEDIUM ENTERPRISES: EVIDENCE FROM TOURISM SECTOR}

6. Barton, C.E. (2010). Understanding corporate social responsibility engagement in small and medium tourism businesses: BA Management in Tourism Thesis. University of Technology. Sydney.

7. Carlsen, J.; Getz, D. and Ali-Knight. J. (2001). The Environmental attitudes and practices of family businesses in rural tourism and hospitality Sector. Journal of Sustainable Tourism, 9(4), 281-297.

8. Carroll, A. B. (1999). Corporate social responsibility: Evolution of a definitional construct. Business and Society, 38(3), 268-95.

9. Ciliberti F.; Pontrandolfo P. and Scozzi B. (2008). Investigating corporate social responsibility in supply chains: A SME perspective. Journal of Cleaner Production, (16), 1579-88.

10. Dahlsrud, A. (2008). How corporate social responsibility is defined: An analysis of 37 definitions. Corporate Social Responsibility and Environmental Management, 15(1), 1-13.

11. Dalíková. I. P. (2011). Corporate social responsibility as a competitive advantage: Proceedings of the 12th Management International Conference Portorož. Slovenia. University of South Bohemia in České Budějovice. Czech Republic.

12. Dewhurst, H. and Thomas, R. (2003). Encouraging sustainable business practices in a non regulatory environment: A case study of small firms in a UK national park. Journal of Sustainable Tourism, 11(5), 383-403.

13. Dodds, R. and Joppe, M. (2005). CSR in the tourism industry: The status of and potential for certification, Codes of conduct and guidelines, World Bank/IFC, Washington, DC. Retrieved 10 May 2013 from: http://siteresources.worldbank.org/INTEXPCOMNET/Resources/CSR_in_tourism_2005.pdf

14. Dodds, R. and Kuehnel, J. (2010). CSR among Canadian mass tour operators: Good awareness but little action. International Journal of Contemporary Hospitality Management, 22(2), 221-244.

15. Dzansi, D.Y. (2004). Social responsibility of SMMEs in rural communities. PhD Thesis. Faculty of economic and management science. University of Pretoria.

16. Eraqi, M. I. (2010). Social responsibility as an innovative approach for enhancing competitiveness of tourism business sector in Egypt. Tourism Analysis, (15), 45-55.

17. European Commission (2003a). Small and medium-sized enterprises (SMEs): What is SME. Retrieved 3 June from: http://ec.europa.eu/enterprise/policies/sme/factsfigures-analysis/smedefinition/index_en.htm

18. European Commission Report (2011). Communication from The commission to The European Parliament, The Council, The European Economic and Social Committee and the Committee of the Regions. The commission, COM (2011), 681 final, Brussels Retrieved 9 July 2013 from:

http://europa.eu/geninfo/query/index.do?queryText.

19. Fox T. (2005). Small and Medium Sized Enterprises (SMEs) and Corporate Social Responsibility: A Discussion Paper, International Institute for Environment and Development (IIED). Retrieved 7 Jan 2014 from: http://pubs.iied.org/G02266.html

20. Graafland J.; Van de Ven B. and Stoffele N. (2003) Strategies and instruments for organising CSR by small and large businesses in the Netherlands. Journal of Business Ethics, 47(1), 45-54.

21. Henderson, J.C. (2007). Corporate social responsibility and tourism: Hotel companies in Phuket, Thailand, after the Indian Ocean tsunami, Hospitality Management, 26(1), 228-239.

22. Jäger, T. (2012). Corporate Social Responsibility in Practice: How do Swedish medium sized IT companies handle CSR? MA Thesis. Chalmers University of Technology. Göteborg. Sweden.

23. Jenkins, H. (2006). Small business champions for corporate social responsibility. Journal of Business Ethics, 67(3), 241-256. 
24. Jenkins, H. (2009). A 'business opportunity' model of corporate social responsibility for small- and medium-sized enterprises. Business Ethics: A European Review, 18(1), 21-36.

25. Kalisch, A. (2002). Corporate futures: Social responsibility in the tourism industry. London: Tourism Concern.

26. Kang, K. H., Lee, S., and Huh, C. (2010). Impacts of positive and negative corporate social responsibility activities on company performance in the hospitality industry. International Journal of Hospitality Management, 29(1), 72-82.

27. Kasim, A. (2006). The need for business environmental and social responsibility in the tourism Industry. International Journal of Hospitality \& Tourism Administration, 7(1), 1-22.

28. Kim, J. E. (2009). Understanding corporate social responsibility in the tourism industry. PhD Thesis, University of Florida.

29. Kort, S. H. (2010). Implementation of corporate social responsibility in the tourism distribution sector. MA European Tourism Management Dissertation, School of Services Management, Bournemouth University. United Kingdom.

30. Lee, S. and Park, S. (2009). Do socially responsible activities help hotels and casinos achieve their financial goals? International Journal of Hospitality Management, 28(1), 105-12.

31. Lepoutre, J., and Heene, A. (2006). Investigating the impact of firm size on small business social responsibility: A critical review. Journal of Business Ethics, 67(3), 257-273.

32. Longenecker, J. G.; McKinney, J. A., and Moore, C. W. (1989). Ethics in Small Business. Journal of Small Business Management, 27(1), 27-31.

33. Luetkenhorst, W. (2004). Corporate social responsibility and the development agenda: The case for actively involving small and medium enterprises. Intereconomics, 39(3), 157-166. Retrieved 12 April 2013 from: http://hdl.handle.net/10419/41767.

34. Mandl, I. and Dorr, A. (2007).CSR and competitiveness. European SMEs good practice. Consolidated European Report. Vienna.

35. Mankelow, G. and Quazi, A. (2007) Factors affecting SMEs motivations for corporate social responsibility. Conference Paper. Australian and New Zealand marketing Academy ANZMAC. The University of Newcastle, Faculty of business \& Law, Newcastle business school. Retrieved 18 March 2013 from: http://anzmac.info/conference/2007/papers/G\%20Mankelow_1a.pdf

36. McDonald, G. M., and Kan, P. C. (1997). Ethical perceptions of expatriate and local managers in Hong Kong. Journal of Business Ethics, (16), 1605-1623.

37. McWilliams, A., and Siegel, D. (2001). Corporate social responsibility: A theory of the firm perspective. The Academy of Management Review, 26(1), 117-127.

38. Miller, G. (2001). Corporate responsibility in the UK tourism industry. Tourism Management, 22(6), 589-98.

39. Moore, G., and Spence, L. J. (2006). Editorial: Responsibility and small businesses. Journal of Business Ethics, 67(3), 219-226.

40. Murillo, D., and Lozano, J. M. (2006). SMEs and CSR: An approach to CSR in their own words. Journal of Business Ethics, 67(3), 227-240.

41. Perrini, F. (2006). SMEs and CSR theory: Evidence and implications from an Italian perspective. Journal of Business Ethics, 67(3), 305-316.

42. Porter, M., and Kramer, M. (2006). Strategy and society: The link between competitive advantage and corporate social responsibility. Harvard Business Review, 84(12), 78-92.

43. Princic, L.; Floyd, M. and Bonham, J. (2003). Engaging small business in corporate social responsibility: A Canadian small business perspective on CSR, Canadian Business for Social $\begin{array}{llllll}\text { Responsibility } & \text { (CBSR). } & \text { Retrieved } & 25 & \text { May } & 2013\end{array}$ 


\section{CORPORATE SOCIAL RESPONSIBILITY IN SMALL AND MEDIUM ENTERPRISES: EVIDENCE FROM TOURISM SECTOR}

http://info.worldbank.org/etools/docs/library/114189/Engaging\%20SME\%20in\%20CSR\%202003.p df

44. Quazi, A.M. (2003). Identifying the determinants of corporate manger's perceived social obligations. Management Decision, 41(9), 822-831.

45. Roberts, S.; Lawson, R., and Nicholls, J. (2006). Generating regional-scale improvements in SME corporate responsibility performance: Lessons from responsibility Northwest. Journal of Business Ethics, 67(3), 275-286.

46. Santos, M. (2011). CSR in SMEs: Strategies, practices, motivations and obstacles. Social Responsibility Journal, 7(3), 490-508.

47. Seilonen, S. and Hsu, Y. H. (2012). Corporate social responsibility: Motivation and implementation in SME's Perspective. BA Thesis. Linnaeus University.

48. Sen, S. (2011). Corporate social responsibility in small and medium enterprises: application of stakeholder theory and social capital theory. PhD Thesis. Southern Cross University.

49. Serwinek, P.J. (1992). Demographics and related differences in ethical views among businesses. Journal of Business Ethics, 11 (7), 555-66.

50. Sheldon, P. J. and Park, S. (2010). An exploratory study of corporate social responsibility in the U.S. travel industry. Journal of Travel Research, 50(4), 392- 407.

51. Spence, L. J. (1999). Does size matter? The state of the art in small business ethics. Business Review: A European Review, 8(3), 163-174.

52. Spence L. and Rutherfoord R. (2001). Social responsibility, profit maximization and the small firm owner-manager. Journal of Small Business and Enterprise Development, 8(2), 126-39.

53. Spence, L. J. (2007). CSR and small business in a European policy context: The 5 'C's of CSR and small business research agenda 2007. Business and Society Review, 112(4), 533-552.

54. Sweeney, L. (2009). A Study of current practice of corporate social responsibility (CSR) and an examination of the relationship between CSR and financial performance using Structural Equation Modeling (SEM). PhD Thesis, Dublin, Dublin Institute of Technology.

55. Tamajón, L.G. and Aulet, X.F. (2013). Corporate social responsibility in tourism small and medium enterprises: Evidence from Europe and Latin America, Tourism Management Perspectives (7), 3846.

56. Tsai, S. and Wang, X. (2011). How CSR creates competitive advantage for SME in Chinese textile industry: A case study of Shokay Co. MA Thesis. Linköping University.

57. Tsai, H.; Tsang K.F., and Cheng K.Y. (2012). Hotel employees' perceptions on corporate social responsibility: The case of Hong Kong, International Journal of Hospitality Management, (31), $1143-1154$.

58. Turyakira, P.; Venter, E. and Smith, E. (2013). Corporate social responsibility for SMEs: A proposed hypothesized model. African Journal of Business Ethics 6(2), 106-19. Retrieved 18 June 2013 from: http://www.ajobe.org/text.asp?2012/6/2/106/111015.

59. Veal. A. J. (2006).Research methods for leisure and tourism: A Practical Guide. $\left({ }^{\text {rd }}\right.$ Ed.).London: Prentice Hall.

60. Vives, A. (2008). Responsible practices in Small and Medium Enterprises. In: G. Aras \& D. Crowther (eds.), A handbook of Corporate Governance and Social Responsibility. pp. (1-22) England: Gower publishing limited.

61. Williamson D.; Lynch-Wood G. and Ramsay J. (2006). Drivers of Environmental Behaviour in Manufacturing SMEs and the Implications for CSR, Journal of Business Ethics, 67 (3), 317-30. 
62. Worthington, I.; Ram, M., and Jones, T. (2006). Exploring corporate social responsibility in the U.K. Asian small business community. Journal of Business Ethics, 67(2), 201-217.

63. Yu, A. I. (2010). Corporate social responsibility and SMEs: Barriers and opportunities in a Swedish perspective, MA Thesis, Stockholm University.

64. Yu, D.C.; Day, J.; Adler, H. and Cai, L. (2012). Exploring the Drivers of Corporate Social Responsibility at Chinese Hotels. Journal of Tourism Research \& Hospitality, 1(4), 1-10.

65. Zientara, P. and Bohdanowicz, P. (2010). The Hospitality Sector: Corporate Social Responsibility and Climate Change. In: Ch. Schott (Ed.), Tourism and the Implications of Climate Change: Issues and Actions (Bridging Tourism Theory and Practice, (vol. 3), pp. (91-111). Bingley: Emerald Group Publishing Limited.

الملخص العربي

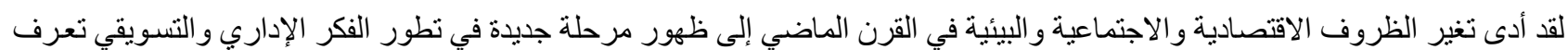

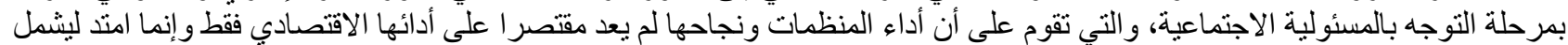

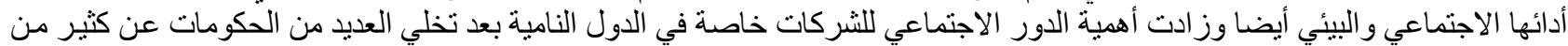

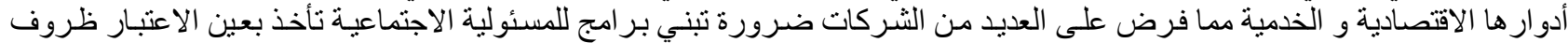

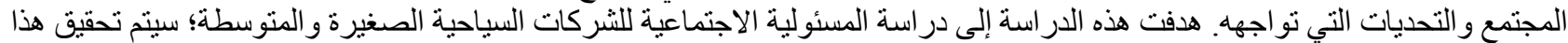
الهدف العام من خلال الأهداف الفر عية التالية: 1. تقديم إطار نظري مفصل عن المسئولية الاجتماعية بثكل عام أو لا ثم بالتطبيق على المشرو عات الصغيرة و المتوسطة ثانيا؛ 2. تقييم مدى وعي شركات السياحة المصرية الصغيرة و المتوسطة بالمسئولية الاجتماعية ومستوى تطبيقها؛ 3. توضيح كيفية تأثير خصائص المشرو عات الصغيرة و المتوسطة فى تطبيق المسئولية الاجتماعية؛

4. تحديد الدو افع التي تحفز شركات السياحة المصرية الصغيرة و المتوسطة على تطبيق المسئولية الاجتماعية و المز ايا التي تترتب على فئى تطبيقها؛

5. تحديد أنشطة المسئولية الاجتماعية التي تمارسها شركات السياحة المصرية الصغيرة و المتوسطة، بالإضافة إلى معرفة التحديات التي تعوق تطبيقها؛

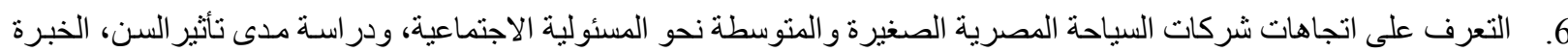
في مجال السياحة و المستوى التعليمي لمدر اء هذه الثركات فى اتجاهاتهم نحو تطبيق المسئولية الاجتماعية؛

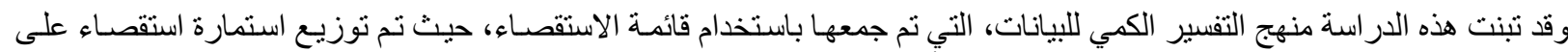

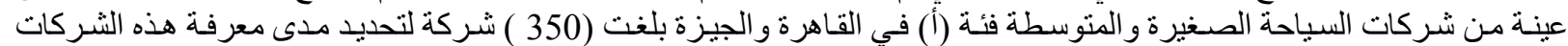

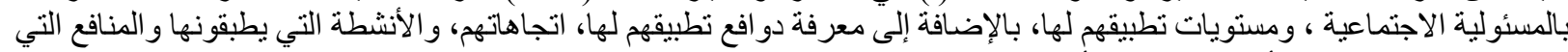
تعود عليهم من تطبيقها، و أخيرا المعوقات أو التحديات التي تو اجهره. 